\title{
Verbal, Non-Verbal Communication and Body Language in Part A of Erotokritos by Vitsentzos Kornaros
}

\author{
V. E. Kostoula, P. J. Stamatis, and L. Christodoulidou
}

\section{ABSTRACT}

This paper studies verbal and non-verbal communication as this is captured in part A of the narrative poem Erotokritos by Vitsentzos Kornaros. First, the paper presents the basic characteristics of the Cretan Renaissance that inspired the author. Then a brief reference is made to the genre of the masterpiece and its classification as a novel. Within the framework of this study, the focus was placed on investigating the content of the verbal communication, as this is identified in the dialogues taking place between the main characters-protagonists of the romance. Moreover, the discussions between Erotokritos and his trusted friend Polidoros as well as between Aretusa and her nurse Frosini are also studied. The verbal communication helps understand the characters' way of thinking and leads to conclusions about social perceptions and public morality concerning love, which is prevalent in the poem. Finally, reference is made to important non-verbal communication channels contained in the text. More specifically, important references to the visual, motor, thermal and tactile communication channel have been identified. The study shows that non-verbal signs express feelings, which are difficult to express in words. As these signs contribute to the plot, they describe the interaction between the protagonists and disclose their feelings in every scene of the play.

Keywords: Communication, Cretan Renaissance, Erotokritos, Non-Verbal Communication, Verbal Communication

\section{EROTOKRITOS WITHIN THE FRAMEWORK OF THE CRETAN RENAISSANCE}

Erotokritos is a masterpiece with a great impact, written during the Cretan Renaissance, when Crete was under the Venetian rule. Already in the $13^{\text {th }}$ century, the first Venetian troops occupied Crete. The Venetians maintained their rule for approximately four hundred and fifty years, until 1669 (Kaklamanis, 2019). In the second half of the $16^{\text {th }}$ century, a society presenting analogies with western European cities of that era was shaped in Cretan cities, with similar economic, social, administrative structure and cultural quests, which led to the Renaissance (Maltezou, 2016).

At the end of the $16^{\text {th }}$ and in the $17^{\text {th }}$ century, Crete seems to have followed, with a slight delay, a parallel course with the Western Renaissance. Crete substantially experienced a late Renaissance. Social and intellectual growth occurred at a slow pace, in contrast to the $16^{\text {th }}$ century of the Italian Renaissance. Cretan literature does not present any contrast to the Middle Ages and it cannot be considered that the basic characteristic of the Renaissance is the contempt of the
Published Online: January 6, 2022

ISSN: $2736-4534$

DOI: $10.24018 /$ ejedu.2022.3.1.231

V. E. Kostoula*

Department of Sciences of Preschool

Education and Educational Design, University of the Aegean, Greece.

(e-mail: kostvaso@ gmail.com)

P. J. Stamatis

Department of Sciences of Preschool Education and Educational Design, University of the Aegean, Greece.

(e-mail: stamatis@ rhodes.aegean.gr)

L. Christodoulidou

Department of Primary School Education, University of the Aegean,

Greece.

(e-mail: louizachrist28@ gmail.com)

*Corresponding Author
Middle Ages. In Cretan literature, there are new elements, different from the byzantine ones. There are, of course, also some topics identified in byzantine romances, too, but they are not sufficient to document this literature as Byzantine (Alexiou, 2011).

The Venetian culture did not have a direct impact on the Cretan Renaissance. As David Holton (2016) points out, "Venice was the channel for the dissemination of the achievements of the Italian Renaissance in Crete". However, as the same researcher points out, Occident and Orient meet in Crete, because "Cretan literature and art of the $16^{\text {th }}$ and $17^{\text {th }}$ century owed a lot to the standards of the Italian Renaissance, but they had their own identity. "Literature of the Cretan Renaissance is not literature translated into Greek; it is underpinned by the local written and oral tradition, which has byzantine roots. Therefore, the creative impetus of Italy of the $15^{\text {th }}$ and $16^{\text {th }}$ century had an impact on the fulfilment of the Cretan Renaissance (Holton, 2016).

The period between 1570-1620 is the period of Cretan literature prosperity. Cretan creators draw their models on the Italian literature of the first decades of the $16^{\text {th }}$ century. 
Ludovico Ariosto, Gian Giorgio Trissino, Antonio Cammelli, Giambattista Giraldi, Torquato Tasso, Luigi Grotto, Battista Guarini and others have had a great impact on them. However, they do not copy these models; on the contrary, they have a creative approach, adapting them to the conditions of their era and place (Kaklamanis, 2019). Kornaros is influenced by the same literary place as his contemporaries in the European context.

To sum up, the use of the term "Cretan Renaissance" does not mean there was a "Greek Renaissance" similar to the western one. Holton (2016) sustains that "the Cretan Renaissance is the result of a wonderful cross-fertilization of cultures taking place in a society that had developed its own uniform character in the $16^{\text {th }}$ century, which was neither Greek nor Italian, but Cretan”. Cretan authors managed to create their own version of ideals and intellect of Renaissance (Holton, 2000). Vitsentzos Kornaros is a creator distinguished for an aesthetic perception that characterizes the European culture of Late Renaissance (Pieris, 2006).

One of the literary genres cultivated during that period was novel. There are many typological definitions for Erotokritos. It is a poem at times characterized as epic and courtly literature but also novel and romantic fairy tale (Kaplanis, 2006) or even a study of manners (ethography), as mentioned by Seferis (1984). Its classification as a novel and, more specifically, as a romantic novel also shows the continuity of the long-standing Greek tradition. It is an ancient Greek genre, quite productive in Byzantium, which constitutes a basic literary genre also in modern times (Beaton, 2006).

This masterpiece is rarely characterized as a "novel" in Greek literature. Modern researchers (Moenning, 2006, etc.) seem to accept the characterization of Alexiou (2016), who considered it a "novel in verse" and, in particular, a "romantic" one. According to Beaton (2006), this work of art belongs to the historic context of the evolutionary course of the novel genre, remaining though obstinately a poem without giving away its lyric and dramatic grace. When Kornaros composed the poem there was no corresponding Greek term for the Italian "romanzo." However, there were narrations in verse of the late and post byzantine production, with a romantic subject, probably known to Kornaros (Beaton, 2006).

Regarding the subject of this work of art, it is useful to point out that Erotokritos does not simply "narrate" the adventures of a couple wishing to join in love, as it is usually the case in the traditional subjects of romantic novels in verse (Alexiou, 2016). The way in which Kornaros handles the subjects belongs to the Renaissance, as great focus is placed on the internal love conflict (Liebeskonflikt) experienced by Aretusa and Erotokritos. Aretusa wishes to marry Erotokritos, although she is aware of the opposite opinion of her father, who wishes to marry her with a husband of her own social class. While such an obstacle appears in late byzantine couples, the subject of internal love conflict does not appear anywhere (Moening, 2016).

On the one hand, Aretusa feels fear and shame towards her father, while, on the other hand, she has to deal with her romantic passion. She struggles not only against her father, but also against herself. Erotokritos experiences a similar conflict, as he falls in love illegitimately with the king's daughter, although he is the king's faithful subject and servant. Both Frosini and Pezostrators, the most trusted people among the main characters of the novel, also face internal dilemmas; however, they give in to Aretusa's and Erotokritos's pressure respectively, to enable the love of the young couple (Beaton, 2004).

\section{Verbal COMMUNiCATION IN THE PART OF EROTOKRITOS}

This paper studies the dimensions of verbal and non-verbal communication in part A of Erotokritos, as they appear in the lines mentioned below based on the edition of the work of art by G. P. Savvidis. Verbal communication, discourse, is an extremely important human achievement used at social and cultural levels. It seems to have a particular impact on human psyche, as it entertains, encourages, comforts, and pleases. In Erotokritos, the importance and psychological dimension of the verbal and mainly of the non-verbal communication become obvious, as thoughts, opinions and feelings are expressed through them (Stamatis, 2015).

Verbal action in the poem seems to take place mainly in the dialogues. The combination of dialogue and narration has a proportion of $42: 58 \%$. Frequent use is made of dialogues and monologues, through which the characters express their feelings, their psyche; they reflect upon their past and future actions (Kaklamanis, 2015).

The percentage of discourses in each of the parts of Erotokritos is as follows: Part A 49\%, Part B 22\%, Part C $62 \%$, Part D 38\%, and Part E 44\%. These percentages show that the emotional evolution takes place in the parts where dialogue prevails. Therefore, dialogue is not an informative means, but a means adopted by Kornaros to explore the reflections and disclose the personality of his characters (Stavrakopoulou, 2017). The extensive use of direct speech in the poem, $42 \%$ in the whole poem and $62 \%$ in part $\mathrm{C}$, is indicative, according to some researchers, despite the objections of some others on this same issue, of the poet's preference for the oral language (Gauntlett, 2004).

The dialogue often illustrates the progressive evolution of the emotional state of the characters and the persistent psychological analysis justifying their actions (Alexiou, 2016). The characters' psychological evolution covers a broad range of feelings: doubt, certainty, fear, anxiety, despair, hope, etc. In general, dialogue animates verbal communication (Stavrakopoulou, 2017). Words have great power. This is pointed out by the poet himself (A 871-874):

Of all the graces a man has, it is words which have the charm

to make every heart take comfort.

A person who knows how to speak with wisdom and skill, can make the eyes of men weep and laugh.

Verbal communication may comfort, raise feelings, and touch emotionally. According to the poet, a necessary condition is the "wisdom" and the "skill," the appropriate communication techniques, persuasion, rhetoric (Kaplanis, 2006). The notion of "skill" obviously refers to the speaker's communication style, which is influenced by the speaker's overall expressive abilities and the possibilities provided by body language (Stamatis, 2013).

The protagonists are introduced by the poet at the beginning of the poem, lines A 51-86. These are the lines of 
“acting”, featuring Aretusa's personality (Kallinis, 2006). She is the king's daughter, she is beautiful, educated and full of grace (Panagiotopoulou, 2006). More lines are dedicated to her (51-70) compared to Erotokritos (77-86), who is the son of a king's counsel. He is also distinguished for his virtues, as he is a handsome and wise young man. The difference in the social status becomes obvious also from the number of lines dedicated to each character.

In the social context of that era, the love between the two young people was "impossible", an adjective in conceptual contrast with what was right to do. This love was not appropriate, according to class requirements. This is verbally depicted in the dialogues of the characters with their trusted people, Frosini and Polidoros (Markomichelaki, 2006). There is also an indicative dialogue developed by Erotokritos with his friend Polidoros, in which the latter considers that this love is dangerous. This love will lead Erotokritos to destruction, as he will be greatly punished. This is why he advises him:

Brother, I never reckoned on what I have heard you tell me,

nor did I expect that you should entertain such a thought and so put yourself in danger.

You seek what is impossible and improper (A 153-156)

But make sure that you give up what neither befits you nor is possible,

in order to conquer them immediately. (A 345-346)

in such a difficult matter, in such an immense task (A 355)

I foresee a sorry end for you and your father.

You will both be expelled from here and made beggars (A182-183)

Polidoros continues to wonder how his friend dared to love a princess. A characteristic element is that the meaning is repeated almost identical over two lines:

making you love a great lady of ours (A 200)

how was it that you fell in love with such a great lady? (A 1131)

Polidoros's words also highlight a small sample of social hierarchy in his era, the king being on the top of the social pyramid and having absolute power over his subjects' life. Therefore, what seemed to Polidoros completely impossible becomes understandable in a society that was structured in this way: a simple son of an aristocrat could simply not claim a royal marriage. The following lines are characteristic:

and he holds our life and our death in his hand (A 214)

For you to want to approach monarchs, kingdoms and riches,

is a very difficult and involved task,

because the difference between the one and the other is great:

men call you small, a king they call great. (A 203-206)

The social distance that separates the couple is pointed out also by Frosini. The characterization of Aretusa as "great lady" is repeated by the nurse but also by the poet himself, while the word "lady" is repeated twenty-five (25) times in Part A! Aretusa has a royal origin, and for this reason, she should marry a man of her own class. This is underlined in the following lines:

A noble woman, child of such a king, a great lady, (A 907) and appear presumptuous towards such a great lady. (A 2154)
Frosini discusses with Aretusa and uses arguments to prevent her from this love. In her pieces of advice, she follows the language decorum (Markomichelaki, 2006). One of her arguments is that in the country, there are no respectful masters or princes worthy of marrying her. In the social hierarchy, they are all inferior, servants. She uses the following words to express her ideas on this issue:

Here there are no king's sons nor other sons of rulers (A 665)

all, madam, are the slaves of your father and servants of yours. (A 668)

On the other hand, Aretusa is the person who represents moral rightfulness. She was raised with principles and, following the ethics of that era, she cannot have a relationship prior to getting married. She does not allow herself to be carried away by her romantic passion (Markomichelaki, 2006). For this reason, in Part A there is no verbal or tactile communication between the couple, only visual contact.

Aretusa herself reassures Frosini:

But do not think that desire is urging me to something unseemly (A 637)

The dialogues are of great interest. They can be considered a "sort of psychomachia" between the protagonist, who expresses the "love impulse", and the trusted person with whom the protagonist has a conversation each time. This constitutes a sort of self-reflection (Peri, 1999). In the dialogue taking place between Frosini and Aretusa, the nurse is the voice of reason and social convention. She uses words to express her concern and love for Aretusa. The poet explains:

As her tender child, not as her mistress, she spoke to Frosini (A 1591).

The latter, in turn, reveals to the nurse her secret love, expressing her desire but also her anxiety. The internal conflict is expressed through her words, as she is afraid of her father's reaction but, at the same time, she deeply feels the desire of love:

I have much to say to you and even though I want to begin (A 1539)

On the one side, I have fear of my father, which is torturing me,

and on the other the pangs of affection and love (A 16271628)

The dialogues between Polidoros and Erotokritos are also revealing. Erotokritos confides in his friend about his secret desire for Aretusa. Polidoros gives his friend wise advice. He cares for him and he doesn't want him to suffer the consequences of a daring romantic relationship with the princess:

Polidoros said to him 'Brother, I wish to talk again

of the misery and confusion which possess you (A 10831084)

Only to Polidoros did he reveal it in full, and some things which he had been hiding he did not now conceal (A 1867-1868)

However, the poem contains limited romantic dialogues and "romantic-sensual elements," contrary to the Greek novel of the Middle Ages. The narrator allows the reader to follow "the lovers ' private communication channel" very few times. The dialogue between Erotokritos and Aretusa starts in Part $\mathrm{C}$ of the poem. Usually, the mediation of the narrator-poet is 
required to transmit these messages to the reader (Lentari, 2006).

\section{NON-Verbal COMMUNICATION IN THE PART OF EROTOKRITOS}

No non-verbal communication between the two young people takes place in Part A of Erotokritos. Non-verbal channels describe graphically and vividly their desire. They communicate with body language, in non-verbal ways and mainly through the visual channel, with their eyes. The eyes and communication with no verbal action are a loan from Petrarch's poems, as Lasithiotakis (1996) mentions. It is worth mentioning parenthetically that several Petrarchan patterns are observed in Erotokritos.

The eye contact, as stated by the verb "see", triggered progressively Erotokritos's desire for Aretusa. The more he looked at her, the more he desired her. For this reason, he decided not to see her, in order to repress his love for her. He believes that by limiting the visual contact he will also avoid the feelings it triggered in him. Erotokritos himself reveals to Polidoros:

My crazed eye increased my desire, (A 291)

And, if I can, my eyes will never again see her. (A 366)

Erotokritos does not dare to talk to Aretusa even when he realizes that she also has feelings for him. He fears she might think he is shameless, and for this reason, he believes eye contact is better and decides to limit himself to this. Humbleness in his look is clearly depicted in the following lines:

He always saw and gazed on her beauty

with meekness and humility (A 2155-2156)

she wishes to see me. This I hold a great gain. (A 2162)

Although she longs to see the young man who is singing, in a scene of the poem, it is revealed that only the impact of the love song that Erotokritos was singing, meaning only listening to his voice and to the content of his lyrics was enough to throw her in the "fire of love." This is pointed out also by Lentari (2012), who mentions that "Her [Aretusa's] love starts with his [Erotokritos's] songs and not with his physical appearance."

It should, of course, be pointed out that it's not only the words of his lyrical songs that touched Aretusa and lit her love fire, but also the melody, the exceedingly sweet voice (A 398) of the singer. Therefore, being anxious to know who the unknown singer was, she reveals her desire to get in visual contact with him. The following lyrics suggest this desire of hers:

I would like to be able to know who he is and to see him often (A 640)

I greatly desire to see the lute player (A 995)

which had blinded her and made her love

one whom she could neither see nor recognize. (A 13051306)

The eyes are the mirror of the soul. When Aretusa discovers her painting, namely her portrait, in Erotokritos's room, her eyes shine, expressing her joy and enthusiasm because the identity of his favourite singer was at last revealed:

And flashes of lightning fell on to her eyes, (A 1491)

Also, at the end of Part A, in her effort not to reveal her love and not knowing anything about love, Aretusa looks at
Erotokritos secretly and shyly. This behaviour corresponds to the ethics of that era. A woman, and especially a princess, could not be the one who would first reveal her feelings to a young man, and that's why her look is so shy:

Now it was as a girl that she watched him with humility and shyness. (A 2078)

On his side, Erotokritos looked at Aretusa sometimes, in order to conclude from the way in which she was looking at him if she loved him:

\section{Sometimes he discreetly looked at Aretusa,}

to discover what the girl's hear and desire were (A 20872088)

The frequent eye contact seems to express the love between the two young people, as progressively the duration of the eye contact increases. Moreover, the look becomes more compassionate and affectionate. This is what the poet mentions:

After many encounters the girl too began

to turn towards him and look upon him with affection (A 2093-2094)

The two young people communicate efficiently by looking at each other. The poet mentions that Aretusa responds to his look and Erotokritos realizes/perceives from her look the love she has for him. Their love was not expressed in a verbal way but was nurtured through the visual communication channel. Aretusa of course kept up appearances to safeguard her honour; that's why she made sure that her look was not completely encouraging. She didn't want to reveal that she had surrendered to her desire. The following lines reveal the power of the eye contact and its role in the communication between the main characters of the poem:

she often replied to him with the corner of her eye (A 2098)

He recognized her heart's pain in her eyes, (A 2117)

one never smiled to the other nor did they talk.

In this way, the time passed. It was only their eyes which confessed the sufferings and pain of their hearts. Aretusa's look shifted between yes and no. (A 2132-2135)

The poet himself also points out the beneficial impact of the eye contact between the two young people in love and observes that the look causes strong emotions between them, such as joy, rejoicing, etc.:

Those who love passionately receive great comfort when they see the beauty of the other's eye.

They rejoice, they take joy in this sight (A 2165-2167)

Polidoros, addressing his friend Erotokritos, encourages him to talk about the love that seems to have had such an impact on him. The latter did not express himself verbally, but the eyes revealed his feelings:

Because, although you do not talk, your eyes confess what your lips are unwilling to tell me. (A 1085-1086)

The value of the eye contact is stressed yet at another point, when Polidoros suggests that the torture of love is born with the exchange of looks:

When eyes do not meet and mingle,

those who love are tortured in vain. (A 1119-1120)

But if the "eyes" see twice or three times that they don't match, they don't "meet," then love will not prosper... Then Polidoros suggests that the eyes can expel love from one's mind. If the eyes see other beautiful young women, they may have a decisive impact and trigger love for another woman. Therefore, in an effort to protect his friend against this love, 
Polidoros encourages him to love another girl through eye contact:

Our eyes alone, as they do the seeing,

have a pact with Cupid, and they keep to one counsel.

They can, when they come to an agreement with him, expel

the first love from the mind and substitute the youth of another. (A 1249-1252)

The impact of love on Erotokritos is also expressed through motor channels concerning his facial expressions and body posture. Only the thought that he will be far away from Aretusa is depicted with horror, sweat and pale aspect:

my limbs grow cold and trembling seizes me.

My eyes grow misty, my appearance is like a corpse,

and the sweat of my death-throes drenches my face (A 278280)

When he decides not to visit the palace often in an effort to forget Aretusa, the consequences of sadness can be perceived in his body:

His body grew thin and trembled like a reed. (A 374)

The lack of eye contact with Aretusa, the deprivation of singing as a means of communication between them has a negative impact on his psyche and becomes visible in Erotokritos's body. Pezostratos is worried about Erotokritos's health and observes:

you are no longer alive but resemble a corpse? (A 770)

Motor channels depict also Aretusa's feelings. When she finds out that he returned from his journey, she is happy, but she cannot express her feelings verbally, in order not to reveal her love. Her facial expressions betray her feelings:

she went pale, she blushed a thousand times in an hour. (A 1766)

Facial expressions depict also Erotokritos's anxiety when he finds out that someone has taken the painting from his room:

His eyes became like those of a corpse; his face remained without living blood, as though dead (A 1797-1798)

Moreover, it's the facial expression what Erotokritos wishes to decode, when he is anxious to know if the king has become aware of his love for Aretusa. He asks Polidoros to visit the king and study his facial expression to understand his mood and intentions. However, the king's laughter reveals his good mood and disperses his fears. The following lines depict his facial expressions:

at the king's face to see if he is enraged, (A 1889)

and talked to him with a smile. The king took much pleasure in him (A 1917)

The importance of facial expressions is clearly stated also by the poet. People's thoughts are well hidden, and sometimes they are not expressed verbally. But they are "reflected" in the facial expressions:

Whoever says you cannot tell what someone is thinking is wrong

because it can be seen on the face without a word being said (A 1931-1932)

When Erotokritos goes to the palace and Aretusa sees him, she chooses not to show her interest first, as this was the right thing to do in that era. However, the description of her facial expressions reveals her feelings. Her excitement is revealed in a non-verbal way with the blushing of her face:

She, in her cunning, did not wish to be the first

to show that she admired Rotokritos's youth.
She went pale and cold, and the same moment

her lovely beauty blazed up and reddened. (A 2061-2064)

Other non-verbal messages clearly depicting the characters' feelings are tears and sighs. Erotokritos sighs because of his desire for his beloved one. He expresses his pain in the same way when he is in Egripos, far away from Aretusa. He reacts in a similar way also when he hears his friend Polidoros's advice trying to prevent him from this love:

His time was spent in misery and sighs (A 99)

and said to his friend with sighs and lamentations. (A 238)

Aretusa's love is also depicted by sighs, as at nights, she cannot sleep because she thinks about her love. This is how she also reacted when she heard Erotokritos's songs under her window, although we "do not 'hear' the songs that triggered the girl's love and desire, since [...] this type words of desire are not exposed unaltered in the text, but is briefly described, filtered by the narrator" (Lentari, 2006). In any case, the reader who is alert will detect in the interventions of the narrator, in the dialogue parts, and more specifically in the dialogues of Aretusa-nurse Frosini and RotokritosPolidoros, the resonance of the lyrics of these songs (Pieris, 2020). When subsequently Aretusa reads the lyrics of the original - as it was pointed out by Holton (1996) and Pieris (2020) - songs, she gets emotional and cries. Some indicative lyrics confirming this fact are the following ones:

like that of a sick man, was disturbed with pains and moans. (A 1046)

With pangs and sighs she spent her nights and days (A 447) I have them written down and I often read them with tears. (A 860)

Lassithiotakis (1992) observes the following about the functional role of the songs: "As something intermediate between a silent compliment and verbal communication, songs - lyrics and music - constitute a typical example of dissimulated discourse. They convey a message twice anonymous, since the singer's identity is not known and the singer's lyrics, exalting the 'sufferings of passion' (A 395), are not addressed directly to Aretusa, but also a message twice personal, since it is sufficient that Aretusa decodes the 'hints' (A 882), to be convinced that this was meant for her (A 879-80), and that finding out the sheet music will allow her to identify the singer."

As characteristically pointed out, Aretusa:

The songs she had heard every evening from her suitor,

she found them all in writing when she opened the cupboard (A 1433-1434).

In this way, she realizes that the songs were addressed to her, and they were Erotokritos's way to express his love for her. Some indicative lyrics confirming this fact are the following:

With pangs and sighs, she spent her nights and days, (A 447)

I have them written down and I often read them with tears. (A 860)

The same non-verbal way of expression is chosen by the protagonist in the discussion she was with Frosini. When the latter advises her to take the young man out of her mind, she burst into tears:

Her eyes ran like a river and made mud upon the ground. (A 1012) 
Crying tears is also Frosini's reaction when she hears Aretusa stating that she found out who the lute-player she loved was and that she will marry him. All this seems unbelievable to her. The princess wishes to marry a young man who is inferior to her! About this fact Kornaros mentions characteristically:

In tears the nurse then said to Aretusa.

'What is this nonsense my ears hear from you?' (A 14451446)

The hearing channel plays an important part in the love that is born between the two young people. Love is depicted in music. In the Cretan society of that era this was a common habit: groups of men accompanied by musicians went out in the evenings to play serenades for girls. Erotokritos chooses to express himself through the art of music. With his lute, he sings in order to relieve the pain of love, but also in order to express his feelings to Aretusa. In company of Polidoros, he spends his nights singing love songs under the window of his beloved one:

His hand was as sugar. He had a voice like the nightingale. On hearing him every heart sobbed and wept. (A 379-380) He said to him, 'My friend, I have taken to song and lute so that they may heal me quickly in my distress.

When I sing and speak of the pain which tortures me,

it seems that water is quenching the fire within me.' (A 391-394)

Erotokritos's songs play an important role in Part A of the poem. In addition to their healing action on him, they seem to have an impact also on Aretusa's heart. The songs trigger love feelings in her, leading her to love him without even having seen him. The poet mentions characteristically:

For his singing all night pleased her so much,

that never put sleep to her eyes. (A 423-424)

and passion began to shoot arrows at her from afar.

Through those songs, without seeing him,

she became entangled in love and began to pine. (A 426428)

The composition of the song and the sweetness of the tune cajoled and enslaved the young maiden. (A 433-434) nor was there one [woman] who loved a man,

without ever having seen or known him. (A 955-956)

Aretusa used to write the lyrics of the songs she heard and learn them by heart. She started wondering who the singer was and evening after evening she had a stronger desire to hear him. It is observed that some lyrics are repeated almost identical, with a slight change in the person, since in line A 627 it is the poet who speaks while in line A 942 it is Aretusa who speaks:

She longed for the lute player, she recalled the singing, (A 627)

All of a sudden, the songs and tunes have beguiled me (A 632)

and I swoon when I remember how he sings (A 636)

I seek the lute-player and remember his song. (A 942)

Erotokritos's songs had a beneficial impact on Aretusa, as listening to them brought peace to her soul and body. For this reason, she seeks to hear the singer again and also see him. Finally, through the songs, direct communication is achieved between the two young people:

When in the night I used to hear the tune for which I longed, my body received solace and joy (A 841-842)

and I shall hear and see who it is that sings for me. (Aa 850)

Communication between the two young people in the poem is also achieved through a painting! Aretusa found in Erotokritos's room a painting that depicted her. Without any verbal communication, she draws her conclusions. The portrait confirmed to Aretusa that the young man she loves is Erotokritos, who also has feelings for her:

There she found a painting and saw a likeness of herself, (A 1475)

She seemed to you to laugh and want to speak, (A 1481)

Another channel expressing love's desire is the thermal one. In Part A as a whole there are lines referring to "love's fire". Through this channel, it can be perceived that progressively Erotokritos's heart was going on fire. Even though Erotokritos feels and understands that the fire of love tends to burn him, he is not discouraged. On the contrary, his love for Aretusa increased progressively and continuously:

He went into the middle of the fire and burned by himself. (A 100)

With time what was slow became eager, and Cupid secretly put wood in the furnace. (A 293-294) And gradually it is fed, it lights up, it flares like a furnace, it scorches badly and harms our body. (A 311-312)

When they approach the fire the heat burns them. (A 322) The blaze in their hearts flares up. Their hope grows (A 1105)

Reference to the tactile channel is limited in the poem, as it is identified only in two scenes. When Frosini advises Aretusa, she seems to have her in her arms. Tactile touch transfers strong feelings (Stamatis, 2015). The affection of the nurse for Aretusa and her advice is combined with a warm hug, revealing the strong emotional bond between the two women. Frosini feels almost maternal love and tries to prevent Aretusa from the socially "inappropriate" love she felt for Erotokritos.

Another reference to the tactile channel that is worth mentioning is identified in the scene in which Polidoros holds Erotokritos in his arms because the latter suffers from love. In this way, he expresses feelings of compassion and support to his friend, even though he does not agree with his love for Aretusa.

\section{CONCLUSION}

Erotokritos is a poem written around 1600, during the period of the Cretan Renaissance. It is a romantic novel in verse dealing with the subject of love in the Renaissance way. The masterpiece has had a huge impact and is a living text for the modern reader. Its study, from the point of view of communication, reveals that the characters of the poem, in their effort to communicate, use mainly body language, exchanging verbal and non-verbal signs, making use of almost all channels of interpersonal communication and mainly the non-verbal one. Kornaros makes sure the characters of Erotokritos communicate by making use of almost the full range of body language. They communicate their thoughts and feelings with their eyes, by exchanging looks, with facial expressions and body movements, with tears and sighs, with the sound of voice as this is heard in 
melodies and music, with songs and their lyrics. Even the painting reveals facts and communicates the romantic feelings that have developed between Erotokritos and Aretusa.

As the study of Part A of the poem shows, the channel most frequently used to highlight and increase the couple's desire is the visual one. The eye contact reinforces the romantic feeling and expresses the feelings of the two young people in love. Something similar occurs also with the hearing communication channel, as the melodic voice stimulates the romantic feelings of the main characters: Erotokritos manages to express his romantic passion through music and songs, while Aretusa is fascinated by hearing his music and song lyrics, which speak to her heart.

At the opposite of all these, there is only the tactile communication channel, which is not used for the couple's communication, as the public morality of that era prohibited explicitly any form of tactile contact, any touch, especially between people pertaining to different social classes. The only exception is the affectionate and comforting embracing, in two cases, between familiar and trusted persons, meaning between Erotokritos and his bosom friend Polidoros and between Aretusa and her nurse Frosini, who had raised her, taking care of her as if she were her daughter.

\section{LIMITATIONS}

In this study, there were some limitations as the poem was approached mainly from a communication point of view, and more specifically from the point of view of the characters' interpersonal communication, as this is depicted in the verbal and non-verbal elements used. However, the study of verbal and non-verbal communication does not cover the whole text of Erotokritos, but only it is Part A. Therefore, the conclusions drawn apply only to this part and not to the whole text of Erotokritos. Authors had to deal with the English translation of the poem. The translation of a poem from Greek into English presents objective difficulties. Nevertheless, the translation by Bets et al. (2004) that was finally chosen is considered as the most reliable one. This translation was published as a prose text, as part of the Byzantina Australiensia series of the Australian Association for Byzantine Studies.

\section{REFERENCES}

Alexiou, S. (2011). Cretan literature and its era. Philological and historic study. Athens: Stigmi.

Alexiou, S. (2016). Vitsentzos Kornaros. Erotokritos. Critical edition. Athens: Ermis.

Beaton, R. (2004). Fictional "virtues" in Erotokritos by V. Kornaros. Diavazo, 454, 78-82.

Beaton, R. (2006). Erotokritos in the historic evolution of novel. In St. Kaklamanis (Ed.), Poetry and perception aspects of Erotokritos (p. 3949). Heraklion: Vikelaia Municipal Library.

Betts, G., Gauntlett, S., \& Spilias, T. (2004). Vitsentzos Kornaros, Erotokritos. Melbourne: Byzantina Australiensia. Brill.

Gauntlett, S. (2004). Orality and textuality in Erotokritos. Diavazo, 454, 8394.

Holton, D. (2000). Studies on Erotokritos and other modern Greek texts. Athens: Kastanioti.

Holton, D. (2016). Cretan Renaissance. In D. Holton (ed.), Literature and society in Crete of Renaissance (p.1-20). Crete: Crete University Editions.
Kaklamanis, S. (2015). Erotokritos in the years of early modernity. In St. Kaklamanis (Ed.), Poetry and perception aspects of Erotokritos (p. 1973). Siteia: Centre of Research and Studies of Cretan Culture of the Municipality of Siteia.

Kaklamanis, S. (2019). Cretan poetry in the years of Renaissance $\left(14^{\text {th }}-17^{\text {th }}\right.$ century). Volume A. Introducation. Athens: National Bank of Greece Cultural Foundation.

Kallinis, G. (2006). The "portrait" of virtue, from the "portraits" of beautiful women of medieval and renaissance novel to the absence of female body in Erotokritos by V. Kornaros. In St. Kaklamanis (Ed.), Poetry and perception aspects of Erotokritos (p. 119-129). Heraklion: Vikelaia Municipal Library.

Kaplanis, T. (2006). Who knows how to speak with wisdom and skill... poetic theory of V. Kornaros on the occasion of poetry comments of Erotokritos. In St. Kaklamanis (Ed.), Poetry and perception aspects of Erotokritos, (p. 369-394). Heraklion: Vikelaia Municipal Library.

Lassithiotakis, M. (1992). Traitement de "la scène de première vue" dans Erotokritos. Revue des études néo-helléniques, I, 1, 53-76.

Lassithiotakis, M. (1996). Petrarchan patterns in Erotokritos. Thisavrismata, $26,145-179$

Lentari, T. (2006). Erotokritos and Greek vernacular novel of Middle Ages: the discourse of desire and its absence. In St. Kaklamanis (Ed.), Poetry aspects in Erotokritos (p. 151-175). Heraklion: Vikelaia Municipal Library.

Lentari, T. (2012). The arrows of love and the eyes of Aretusa: the look decorum in Erotokritos. In T. M. Markomichalaki (Ed.), The world of Erotokritos and Erotokritos in the world (p. 89-103). Heraklion: Municipality of Siteia.

Maltezou, Ch. (2016). Historic and social context. In D. Holton (ed.), Literature and society in Renaissance Crete (p. 21-57). Crete: Crete University Editions.

Markomichelaki, A. (2006). Issues of handling rightfulness in Erotokritos. In St. Kaklamanis (Ed.), Poetry and perception aspects of Erotokritos (p. 355-367). Heraklion: Vikelaia Municipal Library.

Moenning, U. (2006). Genre context in Erotokritos. In St. Kaklamanis (Ed.), Poetry and perception aspects of Erotokritos (75-82). Heraklion: Vikelaia Municipal Library.

Panagiotopoulou, V. (2006). Beauty in Erotokritos: renaissance aesthetic perceptions of Vitsentzos Kornaros. In St. Kaklamanis (Ed.), Poetry and perception aspects of Erotokritos ( $\sigma$. 103-118). Heraklion: Vikelaia Municipal Library.

Peri, M. (1999). Sick of desire. Medicine and poetry in Erotokritos (A. Athanasopoulou, Trans1.). Heraklion: Crete University Editions.

Pieris, M. (2006). From the oppression chronography of Machairas to the romantic novel of Kornaros. In St. Kaklamanis (Ed.), Poetry and perception aspects of Erotokritos (p. 237-247). Heraklion: Vikelaia Municipal Library.

Pieris, M. (2020). The "words of love" or "lyrics of desire". The lyrics of the songs of Erotokritos. Erotokritos. Studies and papers (2006-2019) (p. 79-103). Athens: Nefeli.

Savvidis, G. P. (2016). Romantic poem called Erotokritos. Athens: Ermis.

Seferis, G., "Erotokritos". Essays. Volume A (1936-1947) (p. 268319), Athens: Ikaros, 1984.

Stamatis, P. J. (2013). Communication in Education. Athens: Diadrasi.

Stamatis, P. J. (2015). Preschool and Primary Pedagogy: Communication dimensions of the educational process. Athens: Diadrasi.

Stavrakopoulou, S. (2017). Vocative address in Erotokritos by Vitsentzos Kornaros. In T. Kaplanis, T. Markomichelaki, S. Stavrakopoulou (Eds.), Erotokritos by V. Kornaros. Interpretation proposals and perspectives. Proceedings of international conference dedicated to Komnini D. Pidonia (p. 129-140). Sector of Medieval and Modern Greek Studies, Faculty of Philology, Aristotle University of Thessaloniki, 28-29 May 2015. Thessaloniki: Grafima.

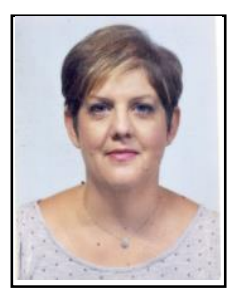

Vasiliki E. Kostoula was born in Rhodes, Greece. She holds a BA from the Faculty of Philosophy, Pedagogy and Psychology, National and Kapodistrian University of Athens (1995) and a MA in Models of Educational Planning and Development, of the Department of Sciences of Preschool Education and Educational Design, University of the Aegean (2016). She is currently working on her PhD thesis in the field of verbal and nonverbal communication. She is a deputy head teacher in an Upper Secondary General School located in Rhodes island-Greece. She is the coordinator of teachers' professional development activities in her school unit. She has published some papers is educational journals. 


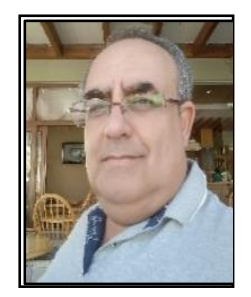

Panagiotis J. Stamatis is Associate Professor of Communication Education in Preschool and Early Primary School Education in the Department of Sciences of Preschool Education and Educational Design, University of the Aegean, Greece. At the same university he studied the Sciences of Preschool and Elementary School Education and he completed his $\mathrm{PhD}$ studies with honors in Pedagogical Communication putting emphasis on Nonverbal Communication in Preschool Education. Since 1989 to 2012 he worked in Primary School Education (PSE), reaping great teaching and administrative experience. He left PSE while he was an Elementary School Teachers' Counselor. He has participated in many conferences as delegate and/or member of several scientific and organizing committees, in educational and research projects and teachers' training programs. He has published pedagogical books in Greece and USA, himself and/or in collaboration. Also, he has reviewed and published several articles in journals, conference proceedings and book chapters. He has given lectures in many institutions and universities. He is a member of the Greek Pedagogical Association and awarded for his writings and social contribution.



Louiza Christodoulidou is an Associate Professor of Modern Greek Literature and Modern Greek Literature of Cyprus. She teaches on both the undergraduate and graduate level in the Department of Primary Education of the University of the Aegean that is based on Rhodes. She was born in Limassol (Cyprus) where she completed her secondary school education. She went on to study in the School of Philosophy of the National and Kapodistrian University of Athens and continued her undergraduate and postgraduate studies in Modern Greek Literature in Paris at the University of the Sorbonne - Paris IV: Maitrise (Master's), DEA (Postgraduate Diploma) and PhD (Doctorate). Her research focuses on Modern Greek literature and Modern Greek literature of Cyprus, Greek women of letters-authors of Asia Minor and Constantinople of the $19^{\text {th }}$ century, Identity/Alterity, historical novel, postcolonial writing, representations of Ancient Greek myth in Modern Greek literature, as well as Francophonia and adolescent and young adult fiction. She has presented papers at many conferences and her research has been published in collective volumes, conference proceedings, Greek and international periodicals in Greece, Cyprus and abroad. 